Britain and the World 5.1 (2012): 69-95

DOI: $10.3366 /$ brw.2012.0035

(C) Edinburgh University Press

www.eupjournals.com/brw

Print ISSN: 2043-8567; online ISSN: 2043-8575

\title{
Civilizing Mission: Animal Protection in Hobart 1878-1914
}

\section{Stefan Petrow ${ }^{1}$}

According to the environmental historian Alfred Crosby, European immigrants arrived in the New World accompanied by, 'a grunting, lowing, neighing, crowing, chirping, snarling, buzzing, self-replicating and worldaltering avalanche'. Animals helped Europeans conquer foreign lands, but soon they were treated as violently and brutally as native peoples. Some colonists reacted strongly against this ill-treatment and took seriously the 1809 injunction by Lord Erskine that animals were not under, 'the dominion of man', but were, 'a dominion in trust'. ${ }^{2}$ All over the British Empire, and indeed the world, animal lovers followed the humanitarian example set by Britain in 1824 and eventually established Societies for the Prevention of Cruelty to Animals. $^{3}$

Stefan Petrow is an Associate Professor in the School of History and Classics at the University of Tasmania, Hobart.

1 The author thanks Hilda Kean for helpful comments on an earlier draft. Alfred Crosby, Ecological Imperialism (Cambridge, 1986), p. 194; see also V.D. Anderson, Creatures of Empire: How Domestic Animals Transformed Early America (Oxford, 2004).

2 Lord Erskine's words were printed on the cover of annual reports of the TSPCA and were derived from his 1809 speech to the House of Lords.

3 K. Shevelow, For The Love of Animals: The Rise of the Animal Protection Movement (New York, 2008), p. 11; Kathleen Kete, 'Animals and Ideology: The Politics of Animal Protection in Europe' in Representing Animals, (ed.) Nigel Rothfels (Bloomington, 2002), p. 25; B. Bonhomme, 'Russian Compassion: The Russian Society for the Protection of Animals-Founding and Contexts, 1865-75', Canadian Journal of History, 45 (2010), p. 262. 
Historians have not given the work of colonial Societies for the Prevention of Cruelty to Animals the same attention as the parent society. ${ }^{4}$ This article will focus on the activities of the Tasmanian Society for the Prevention of Cruelty to Animals (TSPCA) from its formation in 1878. ${ }^{5}$ The Tasmanian Society was directly influenced by the work and publications of its British progenitor and was formed to instil in southern Tasmanians a duty, 'to treat kindly the dumb creatures which ministered so much to man's uses and enjoyments'. ${ }^{6}$ Societies with similar aims were formed in Victoria, New South Wales and South Australia earlier in the 1870s and they exchanged publications with the TSPCA. While animal protection bodies in those colonies have received relatively full histories, the operations of the TSPCA have been neglected. ${ }^{7}$ It differed from the other bodies in placing more emphasis on enforcing the law than on education to protect animals from cruelty in the first three decades of its existence and provides a case study of the effectiveness of the law in, 'advancing the interests of animals ... by the formal imposition of human responsibilities through legal regulation'. The TSPCA did employ an Inspector to investigate cases of abuse and persuade by private remonstrance owners of animals to stop their mistreatment, but it was more willing to enforce the law, especially in extreme cases of cruelty, or to punish recalcitrant owners, despite often facing difficulties gaining successful prosecutions. The TSPCA in effect gave animals a voice in society and in court. This article assesses the work of the society in its endeavours to protect domestic animals, especially horses that were widely used for work and transport. The article also considers attempts to evade and

4 Distinguished examples of work on the RSPCA are Brian Harrison, Peaceable Kingdom: Stability and Change in Modern Britain (Oxford, 1982); Harriet Ritvo, The Animal Estate: The English and Other Creatures in the Victorian Age (Cambridge, 1987); Hilda Kean, Animal Rights: Political and Social Change in Britain Since 1800 (London, 1998). Histories of SPCA's outside England include Beatrice Johnson, For Those Who Cannot Speak: A History of the Canadian Society for the Prevention of Cruelty to Animals 1869-1969 (Laval, 1970), Marion S. Lane and Stephen L. Zawistowski, Heritage of Care: The American Society for the Prevention of Cruelty to Animals (Westport, 2008).

5 The formation of the TSPCA is discussed in T. Bonyhady, The Colonial Earth (Melbourne, 2000), pp. 154-7.

6 Mercury (hereafter M), 20 July 1878, p. 2. The Mercury was the leading daily newspaper in Hobart.

7 W.B. Budd, Hear The Other Side: A History of the Royal Society for the Prevention of Cruelty to Animals in South Australia 1875-1988 (Hawthorndene, 1988); J. MacCulloch, 'Creatures of Culture: The Animal Protection and Preservation Movements in Sydney 1880-1930' (PhD thesis, University of Sydney, 1993), this thesis was not available to researchers at the time of writing this article; B. Pertzel, For All Creatures: A History of the RSPCA Victoria (Burwood, 2006).

8 M. Radford, Animal Welfare Law in Britain: Regulation and Responsibility (Oxford, 2001), p. 11. 
oppose the society inside and outside the legal system. As the Tasmanian society modelled itself closely on the work of the English SPCA, that work is examined in the next section.

\section{Animal Protection in Nineteenth Century England}

At the time Australia was settled in the late eighteenth and early nineteenth centuries, animals were treated brutally on the streets, in the workplace, and in places of entertainment in England. The working classes regarded, 'combat with animals as an inherent part of the "natural" processes of life'. ${ }^{9}$ As a proverb put it in 1825, 'England is the hell of dumb animals,' and brutality continued into the second half of the nineteenth century. ${ }^{10}$ Middle-class reformers led the movement to defend animals from mistreatment for various reasons. Some were opposed to all forms of tyranny, violence and brutality whether against animals or humans and irrespective of class. Such supporters of animal protection joined other causes such as the movement against slavery and believed that, "human and animal causes were interconnected battles against oppression'. ${ }^{11}$ Others linked the protection of animals with disciplining the unruly working classes, but, as they cultivated the support of the powerful, were not unanimous in publicly condemning hunting by the upper classes. ${ }^{12}$ Most reformers regarded treating animals kindly and not inflicting unnecessary pain as the duty of Christians and a hallmark of civilization. ${ }^{13}$ The middle class would provide 'moral leadership' in society by appealing to the feelings of the English people for support in relieving the suffering of helpless animals. ${ }^{14}$ The reformers tried to achieve, as Fudge puts it, 'a new way of thinking about and living with animals', that replaced violent impulses and inflicting pain with restraint and kindness. ${ }^{15}$

9 R. W. Malcolmson, Popular Recreations in English Society 1700-1850 (Cambridge, 1973), p. 136.

10 Quoted in Ritvo, p. 126.

11 Shevelow, p. 13.

12 Ritvo, pp. 133-4.

13 Kathleen Kete, 'Introduction' in A Cultural History of Animals in an Age of Empire, (ed.) Kathleen Kete (Oxford, 2007), pp. 3-4; Chien-hui Li, 'A Union of Christianity, Humanity and Philanthropy: The Christian Tradition and the Prevention of Cruelty to Animals in Nineteenth-Century England', Society E` Animals, 8 (2000): p. 273.

14 Brian Harrison, 'A Genealogy of Reform in Modern Britain' in Anti-Slavery, Religion and Reform: Essays in Memory of Roger Anstey, (eds) Christine Bolt and Seymour Drescher (Folkestone, 1980), pp. 123, 131-2.

15 Erica Fudge, 'A Left-Handed Blow: Writing the History of Animals' in Rothfels, p. 11 . 
From the passing of the Cruelty to Animals Act in 1822 and the passing of many more laws thereafter expanding the definition of cruelty, the law was the main weapon to stop brutality. ${ }^{16}$ Although there was, 'educational and symbolic value in getting kindness to animals incorporated into the law', animals did not gain 'more power' or 'more freedom', and much hinged on effective law enforcement to restrict man's misuse of his dominion over animals. ${ }^{17}$ The SPCA was established in 1824 (becoming the Royal SPCA in 1840), to ensure that the law was rigorously enforced, especially against the 'visible ill-treatment' of horses on urban streets; they wanted to stop cruelty from being encouraged by bad example. ${ }^{18}$ After overcoming initial jealousy and suspicion, the RSPCA secured the co-operation of magistrates and the police, to support the work of its own paid inspectors. Many inspectors had police training, but little experience in dealing with animals or their needs. The RSPCA was one of the few important pressure groups that, 'consistently collaborated with the authorities,' and this resulted in increased convictions for cruelty by 1901 . $^{19}$ Conscious of charges of class legislation, from the 1860s the society stressed that social class was not a factor in deciding to prosecute and by the 1880s employers were being punished for ill-treatment committed by their employees. Nonetheless, most RSPCA prosecutions were of working men because their cruelty was the most visible and its officers were prevented from entering 'private places' where much cruelty occurred because of, 'the sacredness of alleged rights of the citizen, the domicile and of private property. ${ }^{20}$

In the second half of the nineteenth century, some animal protectionists questioned whether using the law was the most effective way to change behaviour and their opponents warned against the dangers of infringing individual liberty by extreme legislation. ${ }^{21}$ Influenced by the, 'evangelical character of activists' Christian faith', by the 1860 s education to reinforce prosecution had become an increasingly important part of the RSPCA's programme. ${ }^{22}$ It aimed to familiarise people with the nature of animal mistreatment and to engender kindness towards animals, but also to persuade onlookers to intervene and stop cruelty. Special efforts were made by the many female members of the RSPCA to educate

16 A penetrating analysis of the various statutes passed in Britain can be found in Radford, pp. 33-89.

17 Harrison, Peaceable Kingdom, p. 121; John Passmore, 'The Treatment of Animals', Journal of the History of Ideas, 36 (1975): p. 212.

18 Ritvo, pp. 138, 146; Kean, pp. 37, 50, 80.

19 Harrison, Peaceable Kingdom, pp. 83, 93, 111, 146-50.

20 Radford, p. 84.

21 Kean, p. 35.

22 Ritvo, p. 147; Chien-hui Li, p. 279; Harrison, Peaceable Kingdom, p. 129. 
children in schools and through the Band of Mercy movement. ${ }^{23}$ Women supplied well over half the legacies left to the RSPCA in the nineteenth century and these were often devoted to educational work. ${ }^{24}$ Churches helped to educate their parishioners with sermons on Animal Sundays from $1865 .^{25}$ The RSPCA skilfully mobilized, 'the general public's enthusiasm and even, on occasion, its sentimentality in defence of animals. ${ }^{26}$ Despite the perseverance and courage of animal protection enthusiasts, the struggle to change cultural attitudes to animals never gained full acceptance and faced ridicule and resentment, evasion and resistance, especially amongst the poor whose recreations and livelihoods they attacked. ${ }^{27}$

The, 'civilizing mission,' of middle class reformers was, 'exported to the colonies,' and found its, 'most telling expression,' in the formation of animal protection societies, 'devoted to notions of progress towards a higher state of civilization'. ${ }^{28}$ The RSPCA noted the formation of these societies in its annual reports, but the exact nature of its relations with colonial societies is unclear. The key decade for the formation of animal protection societies in the Australian colonies was the 1870s when four were formed. ${ }^{29}$ By the 1870 s tolerance of cruelty and immoral behaviour generally had greatly lessened in the Australian colonies and the debate over vivisection in Britain renewed interest in animal protection. The next section explores the context for the formation of the TSPCA.

\section{Changing Attitudes to Cruelty in Hobart: the 1870s}

Settled as Australia's second colony in 1803, Tasmania began life as the island penal colony of Van Diemen's Land. ${ }^{30}$ The name Tasmania was adopted in 1855, but soon after the colony suffered economic depression until the early 1870s; it was the smallest of the eastern Australian colonies but with a sizable population of ex-convicts and their offspring. The brutal treatment of convicts and of the

23 Kean, p. 46; Arthur W. Moss, Valiant Crusade: The History of the R.S.P.C.A. (London, 1961), pp. 196-8

24 Harrison, Peaceable Kingdom, p. 137.

25 Moss, pp. 205-6.

26 Harrison, Peaceable Kingdom, pp. 108, 114, 117.

27 Ritvo, p. 166; Kete, 'Animals and Ideology', p. 27.

28 Dorothee Brantz, 'The Domestication of Empire: Human-Animal Relations at the Intersection of Civilization, Evolution, and Acclimatization' in Kete, pp. 75, 79.

29 Daily News, 22 June 1878, p. 3; Bonyhady, p. 154.

30 Lloyd Robson, A Short History of Tasmania updated by Michael Roe, 2nd ed. (Melbourne, 1997). 
indigenous population during the convict era was matched by the mistreatment of animals. Settlers to the island brought with them the cruel practices of England and 'the dominion of man' was reinforced by the freedom of all classes to hunt native animals for sport and food. ${ }^{31}$ Concerned about the mistreatment of livestock and presumably influenced by the enactment of new English legislation in 1835, the Lieutenant-Governor Sir John Franklin passed legislation against cruelty to animals in 1837, the first Australian colony to do so. ${ }^{32}$ But the Act was limited in focus and seldom enforced. ${ }^{33}$ Further legislation had to wait until after self government was introduced in 1856. Section 83 of the Police Act 1865 dealt with, 'fighting, baiting or worrying,' animals, but it was similarly rarely enforced and cruelty to animals remained entrenched for some decades. In June 1886 a correspondent called 'Viator' told Mercury readers that 'insensibility to animal suffering in the Australian colonies' was worse than in 'more densely populated countries of the world'. ${ }^{34}$ In Tasmania, with its experience of, 'the awful cruelties of the convict era, it seems strange that cruelty to animals, tenfold more horrible and widespread, should be regarded with complacent apathy'.

Some Tasmanians found apathy increasingly intolerable and wanted to distance the colony from the cruelty and brutality of the penal past. ${ }^{35}$ Daniels has characterized the three decades from 1860 to 1890 as a, "period of transition in Tasmanian history from penal settlement to "civilised" society', by which she means a, 'free community, increasingly dominated by the values of the middle class' ${ }^{36}$ These values included sexual purity and restraint, honesty, decency and respect for property and person. During this period the middle class demanded an end to violence, idleness and criminality, the hallmarks of convictism, and worked through many religious and benevolent institutions for the creation of a more respectable society. ${ }^{37}$ This transition was especially obvious in Hobart, the capital of Tasmania, where middle-class Protestant moral reformers demanded that the

31 David Young, Sporting Island: A History of Sport and Recreation in Tasmania (Hobart, 2005), pp. 1-4.

32 Philip Jamieson, 'Animal Welfare: A Movement in Transition,' in Law and History: A Collection of Papers Presented at 1989 Law and History Conference, (ed.) Suzanne Corcoran (Adelaide, 1989), p. 22.

33 M, 11 February 1875, p.3, letter by 'Mingler'; for one example of enforcement see M, 31 May 1866, p. 2; Jamieson, p. 22.

34 M, 23 June 1886, p. 3, letter by 'Viator'.

35 For a snapshot of the penal system see Robert Hughes, The Fatal Shore: A History of the Transportation of Convicts to Australia 1787-1868 (London, 1988), chapter 11.

36 Kay Daniels, 'Prostitution in Tasmania During the Transition from Penal Settlement to "Civilised" Society' in So Much Hard Work: Women and Prostitution in Australian Society, (ed.) Kay Daniels (Sydney, 1984), pp. 23, 49.

37 Peter Bolger, Hobart Town (Canberra, 1973), chapters 9 to 12. 
municipal police force (established in 1858) impose order on the streets by suppressing prostitution, ruffianism and juvenile delinquency and enforcing the liquor licensing laws. ${ }^{38}$

As part of their mission to transform Hobart into a civilized society, middleclass humanitarians in the 1870 s also demanded that official action be taken to stop violence against animals. Criticism was directed at the municipal police for ignoring, 'scenes of brutality,' that regularly occurred on Hobart streets by licensed cabmen and owners of coaches who ill-treated their horses. ${ }^{39}$ According to the Mercury, men who mistreated their horses were often 'exceedingly poor' and 'a false benevolence' prevented interference because imposing a fine, 'might bring ruin to themselves and suffering on their wives and families'. ${ }^{40}$ This allowed 'the most horrible cruelties' to be 'perpetrated with impunity'.

In 1875 the Mercury reflected on the changing views on the treatment of animals over the last fifty years, especially amongst the middle classes in Britain. Although cruelty to animals was, 'inherent in mankind,' and, 'part of our fallen nature', 'acts of barbarism' against animals were moving, 'beyond the pale of good society. ${ }^{41}$ Due to, 'the refining influences of philosophy and religion', 'feelings' towards the lower animals had undergone, 'a great and salutary change,' in all, 'civilised countries'. Public opinion had ended practices like bull-baiting, badgerdrawing, cock-fighting and rat-worrying. Due to the, 'unsleeping vigilance,' of societies for the protection of animals, greater attention was paid to the protection of domestic animals and, 'other harmless and useful creatures'. The Mercury described the RSPCA as, 'one of the grandest institutions of the age,' and urged that a branch be established in Hobart to deal with a range of reprehensible behaviour: overdriving cattle, carrying birds by the feet, harrying pet cats and dogs by 'blackguard' boys on city streets and, the most blatant and widespread practice, mistreating horses. ${ }^{42}$

From the mid-1870s the Mercury regularly pleaded for a branch of the RSPCA to be formed, but a precondition for that development was the modernisation of the law. ${ }^{43}$ Animal protectionists had an ally in the House of

38 Stefan Petrow, 'Arabs, Boys and Larrikins: Juvenile Delinquents and Their Treatment in Hobart, 1860-1896', Australian Journal of Legal History, 2 (1996), pp. 37-59 and 'Creating an Orderly Society: The Hobart Municipal Police 1880-1898', Labour History, no. 75 (1998), pp. 175-94.

39 M, 18 February 1875, p. 2, letter by 'Nec Timeo Nec Sperno.'

40 M, 3 August 1875, p. 2.

41 M, 31 July 1875 , p. 2.

42 For a description of the mistreatment of horses see M, 20 August 1875, p. 3, letter by 'Brake'.

43 M, 23 May 1876, p. 2. 
Assembly in the Fingal farmer William St. Paul Gellibrand. Gellibrand's spinster sister Mary Selina Gellibrand became a stalwart of the local SPCA and no doubt urged her brother to introduce the Prevention of Cruelty to Animals Bill in October 1877. William Gellibrand noted that similar legislation in Victoria, New Zealand and Queensland had worked, 'remarkably well'. The Bill was well received in the Assembly and passed without amendment. ${ }^{44}$ In the Legislative Council only one member opposed the Bill and it was passed with minor amendments. ${ }^{45}$

The Prevention of Cruelty to Animals Act 1877 repealed the 1837 Act. It sought to protect horses, cattle, donkeys, sheep, pigs, goats, cats, dogs and other domestic animals from being, 'cruelly and unnecessarily,' flogged, beaten, overdriven, overridden, overloaded, abused, tortured or otherwise ill-treated. ${ }^{46}$ Offenders found guilty of such offences could be fined up to $£ 10$ in a court of summary jurisdiction. But enforcement remained lax and complaints of cruelty regularly appeared in the press. ${ }^{47}$ The first prosecution under the new Act occurred on 31 May 1878 in the Hobart Police Court when Thomas Haddon was charged by Chief District Constable Quodling with, "cruelly and unnecessarily flogging,' a horse on the Queen's Domain. ${ }^{48}$ The key witness to the cruelty was the solicitor John Mitchell, whose evidence was corroborated by Joseph Turner, the assistant to the Inspector of Stock, and by the police. Police Magistrate William Tarleton found Haddon guilty, but fined him a mere 40 shillings because his, 'large family and probably others would suffer,' if the fine was higher.

While the conviction was, 'unanimously approved,' as giving, 'practical effect to the law', isolated prosecutions needed to be followed by more systematic enforcement of the new legislation by a SPCA. ${ }^{49}$ The cause was spurred on in July 1878 by an act of 'awful barbarity' when boys in Upper Goulburn Street exposed, 'a helpless cat to the worrying of dogs', and then slowly, 'roasted the mutilated, suffering creature to death'. ${ }^{50}$ The outrage was witnessed by, 'respectable women and children', but, 'no voice denounced the crime and no hand was raised to rescue the ill-used animal', which was subjected to, 'deliberate and inordinate wickedness'. Public pressure forced the police to prosecute one of the boys Michael Maguire for throwing the cat on the fire and he was fined $£ 5$. Cruelty

$44 \mathrm{M}, 31$ October 1877 , p. 3.

45 M, 7 November 1877, p. 2, 9 November 1877, p. 3.

46 M, 17 May 1878, p. 3.

47 M, 24 May 1878, p. 3, letter by 'Englishman', 3 June 1878, p. 3, letter by 'Justice', p. 3.

48 M, 1 June 1878 , p. 3.

49 M, 3 June 1878, p. 3, letter by 'Justice', 15 July 1878, p. 2; Third Annual Report of the TSPCA (Hobart, 1881), p. 8.

50 M, 15 July 1878 , p. 2, 19 July 1878, p. 2. 
would continue, asserted the Mercury, unless citizens joined together in, 'a corporate body for the inculcation of the principles of humanity and the strongest punishment of all forms of barbarity. This case was the motivation for 'a small band' of animal lovers to form a local SPCA, which became the most prominent and influential pressure group in late nineteenth century Tasmania and led the, 'crusade against the vice and brutality of the oppression of animal life.' 51

\section{The Formation of the Tasmanian SPCA}

On 19 July 1878 a crowded public meeting presided over by Governor Frederick Weld formed the TSPCA. ${ }^{52}$ Royal endorsement by Queen Victoria had strengthened support for the British SPCA and Weld's presence as the Queen's representative gave the local cause, 'social standing and legitimacy. ${ }^{53}$ The leading speakers highlighted man's duty to, 'brute creation'. Sir James Wilson, member for Hobart in the Legislative Council, pointed out that, 'every civilised community,' needed such a society and that societies had been formed in England, Europe and the other Australian colonies. They should teach the young, 'the duty of humanity towards the lower animals', but also put down such cases as the recent, 'extreme cruelty to a cat,' with, 'the strong arm of the law as an example to all such evil doers'. The religious motivation behind the society's formation was illustrated by Dean H.B. Bromby, who stressed that prevention formed part of, 'their Christian duty'. The Bible enjoined them to treat animals humanely and so did, 'our Saviour's words'. Prevention of cruelty was, 'holy work,' and constituted, 'one of the foundations of Christianity'. Teaching the young to be kind to animals had social benefits: they would in later years, "possess many of the elements of nobility and betray a more considerate tenderness, more moral courage and a more chivalrous bearing towards others'. 54

The Premier W.R. Giblin alluded to the objections to such societies: they were, 'weak and sentimental,' and, 'effeminate,' in caring for, 'the sufferings of the lower order of animals' ${ }^{55}$ Denouncing these, 'erroneous' views, Giblin thought that the society was evidence of, 'the growth of a vigorous and healthy sentiment in the colony'. Cruelty stemmed from, 'the assertion of a sense of dominion over

51 C.E. Walch, The Story of the Life of Charles Edward Walch, with a Selection of His Writings (Hobart, 1908), p. lxxii; M, 2 August 1887, p. 3.

52 M, 20 July 1878, p. 2.

53 Radford, p. 47.

54 Bromby's speech was printed in full from the reporter's notes, see M, 30 July 1878, p. 3 and drew criticism for being 'a combination of fallacies'. See M, 2 August 1878, p. 3, letter by J.L. Livingston.

55 M, 20 July 1878, p. 2. 
the brute creation', but few humans were, 'fit to be entrusted with the absolute dominion of any living thing,' and the society would check, 'the abuse of this possession of powers to ill-treat'. Other speakers singled out the role of women, especially Louisa Ann Meredith and Mary Gellibrand, in the formation of the society.

The new society had a number of aims. One was, 'to prevent cruelty to animals by enforcing, where practicable, the existing laws,' and to seek new legislation when 'expedient'. ${ }^{56}$ The other major aim was to excite and sustain, 'an intelligent public opinion regarding man's duty to animals'. But Governor Weld, who accepted the presidency of the society, introduced a discordant note into the proceedings. He advised the society not to take extreme measures. As he was patron of hunting clubs and was 'an old sportsman', he counselled the society not to be 'hostile' to hunting, coursing or 'similar sports'. Unaware of the contradiction of his position, Weld went on to urge flogging for, 'cold-blooded, brutal and deliberate cruelty,' so that offenders could, 'feel the pain they inflicted upon unoffending and helpless animals'.

Correspondents to the Mercury were quick to denounce Weld's hypocrisy, but saw his comments in class terms, not as warning off the women progenitors of the TSPCA from interfering with manly pastimes. ${ }^{57}$ Former public servant Stephen Owen argued that there was, 'more aggravated cruelty,' and, 'greater intensity of suffering, in the agonising terror and tragic death of the hounded hare,' than in the recent case of cruelty to a cat, whose offenders had been rightly punished. ${ }^{58}$ If the society wanted to raise, 'the moral status of Tasmania', it should avoid, 'all suspicion of according passive sanction of any form of cruelty,' because of, 'either the prestige of gentility, or the sanction of usage'. 'Justice' urged, 'the truly philanthropic public,' not to join the society and argued against enforcing legislation which allowed, 'a class privileged to do with impunity that for which their humbler and poorer fellow citizens are liable to signal punishment'. ${ }^{59}$ Anyone who committed cruelty should be subjected to the law. A third correspondent named 'Tasmanian' thought causing an animal to suffer fear as in hunting and coursing was equally as cruel as inflicting, 'unnecessary bodily pain'. ${ }^{60}$ The Mercury adopted a pragmatic position, pointing out that public opinion would not allow hunting, coursing or fishing to be stopped and the

56 M, 20 July 1878 , p. 2.

57 For a discussion of manliness and hunting see R. Boddice, 'Manliness and the "Morality of Field Sports": E. A. Freeman and Anthony Trollope, 1869-71', The Historian, 70 (2008), pp. 1-29.

58 M, 23 July 1878, p. 3, letter by Stephen Owen.

59 M, 23 July 1878, p. 3, letter by 'Justice'.

60 M, 26 July 1878, p. 3, letter by 'Tasmanian'. 
SPCA would endanger its existence in trying to do so. ${ }^{61}$ 'Tatler', a Mercury columnist, suggested that, although Weld and Wilson were, 'lovers of the chase', this did not mean that the society should not stamp out other forms of cruelty and that it would be fruitless to interfere with what was 'considered universally lawful'. ${ }^{2}$

\section{The Work of the TSPCA 1878-1904}

The TSPCA ignored the controversy created by Weld's remarks and set about organising its work. It became a branch of the RSPCA in England, received advice and publications from its indefatigable secretary John Colam until his death in 1910 and followed its tried and true methods closely. ${ }^{63}$ Colam found it, 'quite refreshing,' to discover, 'the interest which is felt in our cause in the antipodes' ${ }^{64}$ Miss Smith, formerly of Ross, lived in England and represented 'the wants' of the Tasmanian society to the RSPCA. ${ }^{65}$ In 1884 renowned British animal protectionist and Honorary Secretary of the Anti-Vivisectionist Society Frances Power Cobbe asked Mary Gellibrand to be that Society's correspondent for Tasmania, but, as no local experiments on animals apparently occurred, vivisection was not an issue for the TSPCA before 1904. ${ }^{66}$ According to Gellibrand, the TSPCA followed, 'the principles,' and worked in, 'the same spirit,' as the RSPCA when waging their, 'war against cruelty,' and that involved discharging their duty with, 'exactness and freedom from oppressiveness,' and avoiding any, 'abuse of power. ${ }^{67}$ By allying itself with the RSPCA, the TSPCA attempted to demonstrate that it was not an extremist body, but adopted the methods that had proven effective in other jurisdictions.

The TSPCA's first annual report clearly stated that, 'prevention and not punishment was the end to be attained'. ${ }^{68}$ If remonstrance by, 'word or by letter,' did not work and the law was persistently broken, then the perpetrator was prosecuted. But the society strongly believed that, "To educate to right

$61 \mathrm{M}, 26$ July 1878 , p. 3.

62 M, 2 August 1878, p. 3.

63 M, 19 October 1878, p. 2, 26 December 1881, supplement, p. 1; Thirty-Fourth Report of the TSPCA (Hobart, 1912), p. 8; according to some accounts no branches of the RSPCA were established overseas until 1948, Moss, p. 193.

64 M, 2 August 1887, p. 3.

65 M, 10 January 1879 , p. 2.

66 M, 9 December 1884, p. 3; a Tasmanian branch of the British Union for the Abolition of Vivisection was not formed until 1928, M, 18 December 1928, p. 7.

67 M, 15 September 1885, p. 3, letter by M.S. Gellibrand.

68 M, 19 July 1879 , p. 2. 
thinking and right acting is a method more potent for good than to punish for wrong-doing'. After one year's work and thirty prosecutions, the society thought it had demonstrated the need for active supervision of animals and that its aims were not, 'Quixotic, wasting its resources and energies upon the impracticable'. ${ }^{69}$ No mention was made of hunting or coursing. ${ }^{70}$ This reassured Weld that the society had followed, 'a wise course,' and adopted, 'prevention rather than coercion'. ${ }^{71}$ The society described its work as, 'coercive persuasion'. ${ }^{72}$ No prosecution was undertaken without seeking the opinion of leading lawyer John Mitchell, who was the society's honorary legal adviser. ${ }^{73}$ In subsequent annual reports the TSPCA kept reminding fellow colonists of its guiding principles that, 'kindness of rebuke and remonstrance,' was appropriate for offenders who were, 'young and thoughtless, or poor and struggling', but, 'strict justice,' would be applied to, 'the wilfully cruel and cowardly'. ${ }^{4}$

Religious motivations were regularly affirmed at annual general meetings. In July 1880 lawyer John McIntyre suggested that the members were not motivated by, 'pretty sentiment', but wanted to discharge, 'a sacred Christian duty,' and, 'plant and inculcate the principle of humanity'. 75 The duty to be kind and tender to, 'brute creation,' was, 'as much a part of God's law as the command to abstain from falsehood or theft'. He realised that, 'sometimes,' it was necessary, 'to correct these four-footed animals', but they must stamp out the infliction of, 'unnecessary pain', especially if it sought, 'to gratify a cruel instinct'. Some speakers highlighted the wider implications of the TSPCA's work. McIntyre proclaimed that they were, 'humanitarians in every sense of the term,' and tended to the needs of sick and distressed people discovered by the society's Inspector on his rounds. ${ }^{76}$ In October 1883 W.R. Giblin hoped the, 'fostering of right sentiment and feeling about cruelty,' to animals would foster similar feelings about cruelty to women and children. ${ }^{77}$

69 M, 19 July 1879 , p. 2.

70 In 1884 an amendment to the Cruelty to Animals Act designed to stop pigeonshooting prompted a debate on ending hunting, coursing and even horse-racing, but was defeated in the Legislative Council. No mention was made of the TSPCA in debates, see M, 16 July 1884, p. 3 and 17 July 1884, p. 3.

71 M, 19 July 1879 , p. 3.

72 M, 8 August 1879 , p. 2.

73 M, 3 September 1878, p. 2.

74 Second Annual Report of the TSPCA (Hobart, 1880), p. 7.

75 Second Annual Report of the TSPCA (Hobart, 1880), p. 10.

76 M, 19 July 1881, p. 3.

77 M, 23 October 1883, p. 3. 
As the central aim of the society was to prevent cruelty to animals, it needed to make the Tasmanian public aware of the reason for its existence. Soon after its formation the society realised that many people and even police were unaware of the new Act and printed placards and posters outlining the society's aims and sections of the Act, which were circulated in town and country. ${ }^{78}$ In the first year the society also published and circulated copies of the Victorian SPCA pamphlet on protecting horses and Louisa Anne Meredith's address, 'Young Australia,' on how to treat pets. ${ }^{79}$ The press, especially the Mercury, was a useful ally in spreading the aims of the society and denouncing cruelty. ${ }^{80}$ Branches were formed in some country districts such as Spring Bay in 1878, Launceston in 1879, and Stanley and Bridport in $1880 .^{81}$

A crucial step in building caring public attitudes towards animals was to exert influence in day and Sunday schools. ${ }^{82}$ W.J.J. Reynolds informed the society that the teachers and scholars of Goulburn Street School had been members of the Victorian society for three years and applied to join the Tasmanian society in $1878 .^{83}$ Following the Victorian system, the society invited the public schools in Hobart and some schools in the country to join the Scholar's Branch and pay a fee of one penny per year per child. ${ }^{84}$ Essay competitions were held yearly on the subject of, 'man's duty to animals'. Only two schools responded to the first appeal, but others joined later. ${ }^{85}$ By August 1887 over 2000 children had become members of the Scholar's Branch and pledged themselves to prevent, 'suffering or oppression'. 86 The Board of Education agreed to tell teachers about the aims of the TSPCA. ${ }^{87}$ Sunday Schools were asked to urge, 'kindness to animals upon the attention of their scholars,' and four had joined by July $1882 .{ }^{88}$ Following the, 'exact discipline,' of the RSPCA, funds obtained from fines were not used for general running expenses or the Inspector's salary, but were used to pay for

78 M, 24 July 1878 , p. 3.

79 M, 19 July 1879, p.2. Meredith's address has not survived, but would probably have urged children to treat pets kindly and gently as she suggested in her poems, see L.A. Meredith, Grandmamma's Verse Book for Young Australia (Oxford, 1878).

80 M, 27 August 1878, p. 2.

81 M, 25 October 1878, p. 2, 7 June 1879, p. 2; Second Annual Report of the TSPCA (Hobart, 1880), p. 6.

82 M, 27 August 1878, p. 2.

83 M, 17 September 1878, p. 2.

84 M, 19 October 1878, p. 2; M, 19 July 1879, p. 2.

85 M, 6 September 1879 , p. 3.

86 M, 2 August 1882, supplement, p. 1; M, 2 August 1887, p. 3.

87 Press Reports of Meetings, March 1880, NS 647/1/4, Tasmanian Archives and Heritage Office, Hobart (hereafter TAHO).

88 M, 11 October 1879, p. 3; Fourth Annual Report of the TSPCA (Hobart, 1882), p. 11. 
literature for the Scholar's Branch. ${ }^{89}$ A legacy of $£ 100$ left by Margaret Hill was devoted to pay for awards for essay prize winners. ${ }^{90}$

Children contributed to the society's objectives by intervening to stop, 'thoughtless cruelty,' against animals and providing information to the Inspector. ${ }^{91}$ On one occasion some child members were being conveyed to the Bower on Mount Wellington when they noticed that the horses were unfit for the journey. They 'resolutely' refused to continue and so the driver returned to town for, 'a better team'. ${ }^{92}$ In another case two boys from the Hutchins School, Harold Cotton and George Audley Coote, who witnessed the brutal use of horses on the Sorell conveyances, told the society and bravely gave evidence in court against the driver. ${ }^{93}$ Equally impressive was the example set by Lillie Browne, who told a carter overloading a dray that he was, 'doing wrong.' ${ }^{94}$ The man responded with, 'rough language', but she continued to reason with him and prevailed.

Another crucial way of spreading its message was through the inspection work of the key officer the Inspector. The first Inspector was George Stuart, the visiting officer of the Board of Education, who was employed until July 1880 when retired police Sergeant Patrick Duggan was appointed. ${ }^{95}$ Duggan was, 'an esteemed ex-member of the force,' and his appointment was expected to improve co-operation with the police. Duggan remained the society's inspector until his death in September 1895 when another ex-policeman Robert Large was appointed to the position. The Inspectors visited various workplaces where livestock were used or housed such as the wharves, stables, quarries, the railway station, cab stands, public pounds and sale yards. Pets kept in spaces around houses also received attention from the Inspectors, who traversed Hobart and surrounding suburbs and districts warning citizens to treat their animals kindly. Duggan sometimes, 'maintained a strict watch throughout the night,' in his quest to accumulate, 'proof positive,' that an offence had been committed. ${ }^{96} \mathrm{He}$ extended his supervision beyond the suburbs of Hobart to Glenorchy, Bellerive, Sorell, Huonville, Brighton and Bridgewater. ${ }^{97}$ To Duggan's, 'unwearied

89 M, 15 July 1880, p. 3, 2 April 1891, p. 3, letter by M.S. Gellibrand.

90 Second Annual Report of the TSPCA (Hobart, 1880), p. 8.

91 M, 29 December 1880, p. 3.

92 M, 5 February 1881, p. 3.

93 M, 26 September 1882, supplement, p. 1.

94 M, 23 October 1883, p. 3.

95 M, 8 August 1878, p.2, 15 August 1878, p. 2, 15 July 1880, p. 3; Second Annual Report of the TSPCA (Hobart, 1880), p. 7, M, 11 November 1880, p. 3, 14 September 1895, p. 4, 24 September 1895, p. 2.

96 M, 11 June 1881, p. 3, Sixth Annual Report of the TSPCA (Hobart, 1884), p. 6.

97 Press Reports of Meetings, 10 August 1881, NS 647/1/4, TAHO. 
industry, discretion and courtesy, the cause of humanity owes its strongest support,' went the TSPCA annual report of $1884 .{ }^{98}$ Large was equally conscientious in his work and remained the Inspector until his death in 1930. ${ }^{99}$ The society often called on Archibald Park's free services as honorary veterinary surgeon to assess the injuries to animals. ${ }^{100}$ Park spent much time on SPCA work, 'sometimes ... to the detriment of his professional business'. ${ }^{101}$

The society relied on informants whose names and addresses were kept, 'strictly private', but the society would not follow up on complaints unless those details were supplied. ${ }^{102}$ The Inspectors registered the names of anyone found guilty of cruelty and kept a record of cautions and remonstrances. ${ }^{103}$ They initially tried, 'every power of private remonstrance before resorting to publicity and punishment'. ${ }^{104}$ This approach was often taken with dogs and cows. Duggan was unceasing in his remonstrances to dog owners to loosen chains and to provide, 'a constant supply of water,' and, 'good sheltering'. ${ }^{105}$ In many cases this, 'speaking for the dumb creatures greatest wants', had stimulated, 'a blessed germ of considerate care,' and gave the society faith that education could eradicate much thoughtless cruelty. The Impounding Act required, 'prolonged detention,' before milking was allowed and this caused cows, 'much suffering'. ${ }^{106}$ Calves were also muzzled before being sold, which was painful. The society posted handbills in the sale yards warning sellers of cows to stop those practices and, following the example of the RSPCA, threatening prosecution if they continued. ${ }^{107}$ Later advertisements were placed in newspapers cautioning owners against these and other, 'barbarous practices', such as, 'the brutal wholesale extraction,' of dead calves instead of, 'gentle and piecemeal removal'. ${ }^{108}$

By 1884 the society could find, 'evidences everywhere to prove that the hearts of the people deeply realise the moral obligation of justice,' for, 'oppressed and speechless,' animals. ${ }^{109}$ Owners of animals who had criticised the society for its, 'undue and vexatious interference,' realised, 'its worth in protecting their

98 Sixth Annual Report of the TSPCA (1884), p. 6.

99 M, 25 November 1930, p. 6.

100 M, 19 July 1879 , p. 2.

101 M, 24 July 1879, p. 2.

102 M, 1 November 1878, p. 2, 18 April 1879, p. 2.

103 M, 3 September 1878, p. 2.

104 M, 10 September 1878, p. 2.

105 Seventh Annual Report of the TSPCA (Hobart, 1885), p. 6.

106 M, 11 June 1881, p. 3, 14 September 1881, p. 2.

107 Press Reports of Meetings, 10 August 1881, NS 647/1/4, TAHO.

108 Seventh Annual Report of the TSPCA (Hobart, 1885), p. 8; M, 3 August 1885, p. 2.

109 Sixth Annual Report of the TSPCA (Hobart, 1884), p. 7. 
property, and increasing the value of their animals. ${ }^{110}$ The rural and municipal police increasingly showed a greater, 'spirit of sympathy and comradeship,' and had experienced, 'considerable annoyance, trouble and much bodily fatigue,' when enforcing the law, but this support ebbed and flowed. ${ }^{111}$

Yet residual opposition remained, as the Reverend George Clarke pointed out in December 1884. ${ }^{112}$ One objection was that women dominated the society and they caused, 'all the mischief, presumably because of their alleged emotional response to animal cruelty. The membership figures listed only about forty-eight women of some 298 members by December 1885, but certainly Gellibrand and her friend Fanny Garrett were pillars of the society. ${ }^{113}$ Another criticism was that a lay society was usurping the role of the police, who should be left to enforce the law. ${ }^{114}$ But the society only acted when the police did not. Finally, the society was caricatured as trying to rid the world of pain, but Clarke pointed out that this was impossible and that their aim was to prevent, 'needless pain,' inflicted on animals from, 'carelessness, wilfulness, indifference and neglect,' and, 'positive brutality'. In this way the society could achieve, 'simple justice to animals'.

That a certain ambivalence about the work of the society remained in political circles emerged during a debate in the House of Assembly in September 1885. Well-known hunting enthusiast and member for West Devon Edward Braddon moved for a select committee to be appointed into the Prevention of Cruelty to Animals Act. ${ }^{115}$ Braddon disclaimed any intention of attacking the TSPCA, but wanted to, 'strengthen,' the work of that, 'exceedingly useful,' body and extend the scope of the Act. He cited the, 'very great amount of cruelty practised on coach horses', which escaped the province of law because of lax enforcement by the police. But Braddon claimed that, 'many people felt aggrieved,' by the actions of the society. He condemned examples of, 'ill-advised action,' by some TSPCA members, which put people to, 'inconvenience,' and, 'pecuniary loss without sufficient reason'. Braddon referred to the case of an unnamed man charged with over-driving a horse, who chose to defend himself in court. The magistrate dismissed the case, but required the defendant to pay two guineas in legal fees. Another northern member Thomas Reibey supported greater efforts to stop, 'the large amount of brutality,' that occurred, especially in his beloved

110 Sixth Annual Report of the TSPCA (Hobart, 1884), pp. 7-8.

111 M, 9 December 1884, p. 3; Seventh Annual Report of the TSPCA (Hobart, 1885), p. 6.

112 M, 9 December 1884, p. 3.

113 Seventh Annual Report of the TSPCA (Hobart, 1885), p. 9.

114 M, 9 December 1884, p. 3.

115 M, 25 September 1885, pp. 3-4. 
horse-racing. But he thought in Tasmania that, 'the poorer classes,' were prosecuted for many evils such as drinking, gambling and flogging cart-horses, while the rich and the well-educated witnessed cruelty on the race track that, 'ought to be met with condign punishment'.

Southern members opposed the motion. Attorney-General Dodds thought Braddon had not made out a case for the select committee and that the existing law was stringent enough when enforced. ${ }^{116}$ Defending the society, William Gellibrand pointed out that it had brought many cases before magistrates and few were dismissed, usually, 'from want of evidence or discrepancy on the evidence'. The committee always thought carefully before prosecuting and in no case had any Tasmanian magistrate awarded costs against the society for, 'vexatious,' prosecutions. Another supporter of the society, R.J. Lucas, thought that if the motion was passed, it would intimate that the society was not doing its duty, but Lucas thought it did do its duty, 'faithfully and well'. The House agreed and defeated the motion nineteen votes to five.

At its October meeting the committee of the TSPCA discussed the Assembly debate and Braddon's further proposal that its funds be matched pound for pound by the government. The committee adhered to the, 'honourable principles,' of the RSPCA that it should remain independent of the state and not accept government subsidy. ${ }^{117}$ The committee also judged that, 'all the provisions,' of the Act had proven necessary and had not been abused. The case cited by Braddon occurred in 1883 and involved a man named Phillips, who was charged with using a horse with broken knees. When asked by Duggan to rest the horse, Phillips threatened to sue the society for loss of earnings and the committee had no choice but to test the case in court. The court supported the right of the society to prosecute by refusing Phillips' application for costs.

The society was an active public body until 1891 when the Bank of Van Diemen's Land collapsed, making money tight and forcing the society to rely on a few members able to pay their fees. ${ }^{118}$ So restricted, the society could not afford to hold public meetings and print annual reports. Despite failing health, Gellibrand, 'supported and directed operations,' of the society, donated her own money and supervised Duggan's and Large's work until her death in $1903 .{ }^{119}$ Gellibrand wrote many letters to the newspapers explaining the society's actions and philosophy and taking responsibility if the Inspectors were criticised. The society

116 M, 25 September 1885, pp. 3-4, 22 October 1885, p. 3.

117 M, 22 October 1885, p. 2, 6 November 1885, p. 4.

118 M, 27 August 1904, p. 7; Tasmanian News, 30 August 1904, p. 2.

119 Sixth Annual Report of the TSPCA (Hobart, 1884), p. 9; Examiner, 14 December 1903, p. 6. 
taught the, 'thoughtless ... to govern their tempers,' and to realise that, 'only the brutal and the cowardly will cause unnecessary suffering to animals' ${ }^{120}$ The society's message was that animals can be tamed more, 'by kindness and patience than by any violence', which made animals, 'vicious and obstinate'. That, 'a great deal of quite wanton cruelty,' remained after 1891 was not supported by the criminal statistics. Between 1878 and 1890 the average annual number of prosecutions was 67.3, while between 1891 and June 1904, when the society's public presence lessened, the average was $22.4 .^{121}$

Most of those prosecutions involved cruelty to horses, which were numerous, for they were used in many different occupations and for transport for residents and tourists. ${ }^{122}$ As Kean has argued for Britain, their mistreatment was clearly visible on city streets and showed that the society's intervention was based on real evils not emotional overreaction. ${ }^{123}$ As Hobart's population grew from around 23,633 in 1881 to 38,391 in 1911 , land available for livestock decreased. ${ }^{124}$ As the total number of horned cattle, sheep and pigs had gradually dwindled to 132 by 1911, the number of horses had remained relatively stable, with 1848 in 1860 and 1253 in 1911. An analysis of how the TSPCA tried to protect horses reveals the nature of its work and the obstacles it faced.

At first Inspector Stuart tried to persuade individual owners to rest injured or tired horses. He advised owners not to turn the hose on horses, heated and exhausted by fatiguing work', which damaged their health. ${ }^{125} \mathrm{He}$ advised cab owners that clipping horses in cold weather deprived them of, 'the protection of their winter coats'. Some owners reprimanded their workers for mistreating horses and thanked Stuart for his information. ${ }^{126}$ Even more gratifying was the example of labouring men and women preventing 'ill-usage' either by personal remonstrance or giving information to the TSPCA, but this was rare and subjected them to, 'some ill-will and neighbourly disfavour'. ${ }^{127}$ In June 1879 Gellibrand reported that the society investigated every allegation of 'ill-usage' and received, 'the willing co-operation of all those with whom it became their

120 M, 10 February 1905, p. 4.

121 These averages are drawn from the incomplete statistics found in annual reports of the TSPCA.

122 The economic importance of horses in Tasmania has been shown in K.M. Dallas, Horse Power (Devonport, 1968).

123 Kean, pp. 39-69.

124 These figures and in the next sentence are taken from the Statistics of Tasmania published by the government.

$125 \mathrm{M}, 1$ October 1878 , p. 3.

126 M, 19 October 1878, p. 2.

127 M, 28 November 1878, p. 2. 
duty to remonstrate. ${ }^{128}$ This proved that cruelty was due to, 'ignorance or thoughtlessness,' and not, 'wilful barbarity,' and that the work of the society was, 'understood'.

Rather than intervene itself, the society at first urged the police in towns and rural districts to enforce the law, but they did not uniformly do so. ${ }^{129} \mathrm{Few}$ constables had sufficient, 'practical knowledge,' to testify whether a horse was suffering from ill-use. ${ }^{130}$ The police were not trained in such matters and did not know that all young horses, 'suffer more or less, and must be kept at work to allow them to harden,' or they became, 'a constant source of annoyance'. Frequent reports of overloading of drays on the Huon, New Town and Sandy Bay Roads were ignored by the police and forced the society to act. ${ }^{131}$ Some cases could not be prosecuted because of the difficulty in getting evidence when the offenders were, 'of respectability', but the committee was not afraid of punishing the rich. ${ }^{132}$ In 1879 it prosecuted one of its own members, James Gregory, for overusing an old and injured horse. ${ }^{133}$ But the society was wary of punishing poor and ignorant owners to avoid allegations of oppressing or unduly punishing anyone. ${ }^{134}$ The society did not proceed with a prosecution in March 1879 for burning the lampas from a young horse's mouth after believing the offender's plea that he did not know that the practice was cruel. ${ }^{135}$

Cab owners were in a different category. They knowingly overused and under cared for horses. In February 1879 the TSPCA tried to awaken them to their responsibilities by sending ten of them copies of the Cruelty Act, the society's handbills and the VSPCA pamphlet, 'Claims of Animals. ${ }^{136}$ Overloading of cabs continued, but the TSPCA felt powerless to stop it. The power to prevent overloading of public conveyances fell within the jurisdiction of the police by section 153 of the Police Act $1865 .{ }^{137}$ In one case two omnibus horses were worked so hard that at the end of the day they could barely, 'crawl along.' ${ }^{138}$ After the society asked the City Council to stop, 'this very cruel custom', the

128 M, 20 June 1879, p.3.

129 M, 19 October 1878, p. 2.

130 M, 22 June 1886, p. 3, letter by 'Justice'.

131 M, 22 November 1878, p. 2.

132 M, 13 December 1878, p. 2.

133 M, 8 September 1879, p. 3, letter by James Gregory and 10 September 1879, p. 3, letter by W. Gellibrand.

134 M, 25 December 1878, p. 2.

135 M, 7 March 1879, p. 3.

136 M, 7 February 1879, supplement, p. 1.

137 Press Reports of Meetings, January 1880, NS 647/1/4, TAHO.

138 Press Reports of Meetings, February 1880, NS 647/1/4, TAHO. 
newly-appointed Superintendent of Police Frederick Pedder ordered his men to prevent overloading of omnibuses and night cars. ${ }^{139}$

Harder to deal with was the persistent working of horses that were lame or, 'weakened by age and insufficient food'. ${ }^{140}$ The society regularly noted examples of feeble and thin horses on cab stands caused by, 'scanty feeding and general inattention'. ${ }^{141}$ It was difficult to prove, 'actual cruelty,' under the Prevention of Cruelty Act because of, 'technical difficulties,' and it would take a long time to eradicate the mistreatment by, 'isolated punishments'. The mistreatment could be stopped in a day if the Mayor used his powers under sections 136 and 137 of the Police Act and ordered monthly inspections of horses on cab stands. The TSPCA received support from the recently formed Hobart Town Cabmen's Protective Union, who wanted to raise their status, 'socially and morally,' and stop mistreatment of horses. This is another example of how the society's publicity and teachings in how best to treat animals could gradually change working-class attitudes, but it also showed that the success of its message depended on individuals wanting to change that behaviour. Six members of the Cabmen's Union were appointed honorary members of the TSPCA. After the Mayor W.H. Burgess visited the cab and car horses, he ordered that horses whose condition, 'evidenced wilful neglect and under-feeding,' should be withdrawn from service. $^{142}$

Burgess' successor as Mayor James Harcourt was also sympathetic to the society and in 1882 appointed Acting-Sergeant Franklin to regularly inspect all horses used by licensed vehicles with Duggan and relieve unfit horses from work. ${ }^{143} \mathrm{Cab}$ drivers tried to evade this inspection in ingenious ways. They used acid and plugs of grease and hair that were designed to conceal wounds. ${ }^{144}$ The acid was, 'the most cruel agent,' because it scorched the skin, caused great pain and left a suppurating sore even larger and more painful than the original injury. Horses with injured or broken knees, caused by poorly-made roads, were still used by cab owners, who covered up the injuries using black ointment or knee caps. ${ }^{145}$ Even when guilt was proved, magistrates inflicted, 'trifling punishments,' because of the poverty of offenders. ${ }^{146}$ The society believed that it was an, 'error of justice,'

139 Press Reports of Meetings, February and March 1880, NS 647/1/4, TAHO.

140 M, 8 August 1879 , p. 2.

141 M, 15 July 1880, p. 3; Second Annual Report of the TSPCA (Hobart, 1880), p. 7.

142 Town Clerk, to Secretary TSPCA, 27 July 1880, MCC 16/7/7, p. 608, TAHO; M, 14 August 1880, p. 3.

143 M, 25 October 1882, supplement, p. 1.

144 M, 18 June 1883, p. 3.

145 M, 24 February 1879, p. 2, 21 March 1879, p. 2, 4 April 1879, p. 2.

146 Seventh Annual Report of the TSPCA (Hobart, 1885), p. 6. 
to award small fines for, 'deliberate and repeated offences', weakening, 'the vigour and discipline,' of the law and the effect of the society's, 'teaching of humanity'. With time the society found that cautioning offenders did not work effectively because, 'the wilfully cruel man,' took advantage of, 'mistaken leniency,' to continue to work unfit animals many times until he was prosecuted. ${ }^{147}$

Members of the TSPCA responded to needy offenders by giving some poor families sustenance from their own pockets while they rested an injured or tired horse, buying a new collar, lending others money to buy, 'a fresh horse', or buying a, 'wretched worn-out animal,' so it could be destroyed. ${ }^{148} \mathrm{Cab}$ and cart horses felt the extremes of winter and members of the society gave seventy-two rugs to keep them warm while standing still. But the society found that such kindnesses, 'induced fresh infractions of the law, and Duggan had to prosecute again. Or the kindness resulted in the increased trafficking of, 'poor worn-out suffering horses, cruelty thereby assuming a given money value'. Weak enforcement of the law and actions of generosity combined, 'to crush down the fear of punishment, and ... to strengthen the power of lawlessness'. Duggan had discovered examples of unfit horses being passed through the hands of multiple owners, with one case involving twenty-two owners. Some horses sold for 5 shillings and some were 'raffled' in a public house for half-a-crown. The non-enforcement of the Police Act against omnibuses, cabs and cars allowed horses with 'tottering' gaits and, 'emaciated frames,' to endanger the 'public safety' and defy, 'humanity'. In 1885 two horses fell exhausted on to the streets, 'the last compulsory effort proving too much for aged frames weakened by semi-starvation'.

Although in England, claimed Gellibrand, the working of, 'worn out and impoverished,' horses was 'stringently' punished, local magistrates pointed out that the Police Act placed the onus on the City Council to stop the use of, 'all unfit and unsafe horses'. ${ }^{149}$ The City Council finally acted decisively in 1890 when Mayor John Watchorn ensured greater attention was paid to supervising cab horses and dealt with, 'some abuses,' that had previously been ignored. ${ }^{150}$ This greatly improved the way that cab horses were treated, but, 'the poor omnibus horses,' were licensed and supervised at the Police Office and only the Police Magistrate had the power to stop the overloading of passengers. Mary Gellibrand called this, 'licensed cruelty,' because those in authority did not enforce, 'proper restrictions'.

147 M, 2 August 1887, p. 3.

148 M, 21 October 1878, p. 2; Seventh Annual Report of the TSPCA (Hobart, 1885), p. 7; M, 2 December 1885 , p. 3.

149 M, 30 December 1885, p. 3, letter by M.S. Gellibrand.

150 M, 14 March 1890, p. 3, letter M.S. Gellibrand. 
The overworking of coach horses worsened to the extent that tourists from an unnamed, 'neighbouring colony,' described their condition in 1899 as, 'a disgrace to Tasmania and a blot on civilisation'. ${ }^{151}$ The SPCA investigation revealed some improvements. Horses were no longer driven with sores or, 'cruelly flogged,' and were mostly, 'well fed and fairly tended'. ${ }^{152}$ But profit-hungry coach owners still used too few horses for too many passengers with heavy luggage and used weakened and small horses too often on long stages without adequate rest. In many cases of cruelty the offenders pleaded guilty and escaped with a small fine, but if evidence had been presented and witnesses examined, 'a much heavier penalty,' would have been inflicted. ${ }^{153}$

Duggan invariably found that many owners and drivers of cart horses responded willingly to his suggestions. ${ }^{154}$ For example, he dealt with overloading by wharf draymen by holding a conference with the owners of the horses, who agreed to stop the, 'ill-usage'. ${ }^{155}$ He was supported by the lessee of the market and the weighbridge clerk. But the overloading of drays, sometimes with, 'extreme weight', continued to be common. ${ }^{156}$ Owners did not seem to realise that this, 'abuse of horse strength ... slowly but surely depreciated the value of their property,' and caused, 'permanent injury'. Some owners tried to evade the law by giving, 'fictitious names,' or the names of those long since dead or who had left the colony. ${ }^{157}$ Others used children as drivers. A baker named Ray used an eleven year old boy as a driver of unfit horses that had been, 'prohibited from work,' in the hope that the society would not prosecute someone that young. ${ }^{158}$ The committee condemned, 'the culpable laxity', of allowing children to drive horses, which risked human life and perpetrated a, 'wicked cruelty'.

Duggan was mostly judicious in the cases he brought to court and often gained a conviction, failing, thought the Mercury, only where an, 'unscrupulous line of defence,' was adopted. ${ }^{159}$ Police Magistrate Tarleton thought the Cruelty to Animals Prevention Act was, 'a very proper Act', but, 'such a highly penal statute,' demanded that knowledge of guilt had to be clearly proved. ${ }^{160}$

151 M, 31 March 1899, p. 2.

152 M, 11 April 1899, p.3, letter by M.S. Gellibrand.

153 M, 1 October 1904, p.6.

154 M, 11 September 1880, p. 2.

$155 \mathrm{M}, 11$ October 1880 , p. 3.

156 M, 11 June 1881, p. 3; Third Annual Report of the TSPCA (Hobart, 1881), p. 6; M, 26 December 1881, supplement, p. 1.

157 M, 17 April 1879, p. 2.

$158 \mathrm{M}, 25$ October 1882, supplement, p. 1.

159 M, 3 January 1882, p. 2.

160 M, 29 March 1879, 2, 30 April 1879, p.2. 
Sometimes Tarleton censured Duggan's, 'somewhat exaggerated tone and style'. ${ }^{161}$ Sometimes he dismissed cases for unfathomable reasons. ${ }^{162}$ In February 1880 Tarleton dismissed two cases against James Hogan for using unfit horses in his carting business and accused Duggan of persecuting him. ${ }^{163}$ The committee thought Tarleton's view of the society's methods was based on, 'erroneous information'.

The Acting Chairman of the TSPCA James Macfarlane defended Duggan's, 'cautious, considerate and yet energetic' methods. ${ }^{164} \mathrm{He}$ reiterated that they used the law only against, 'very flagrant cases,' after an information had been sworn first, but for every prosecution at the Police Office at least twenty cases of cruelty escaped punishment because of the, 'difficulty of legal proof and nonwillingness of witnesses'. As the, 'influence of kindness,' had, 'never been forgotten', the committee felt, 'surprise and pain,' when reading Tarleton's remarks and denied that they had abused their power. Macfarlane pointed out that Tarleton had seen Hogan's horse nineteen days after the cruelty had been first discovered and the wound had healed. As to the accusation of persecution, Macfarlane pointed out that Hogan and his employees had been convicted six times for cruelty before Tarleton himself, three times by the police and three times by the society.

The Mercury agreed that the evidence presented in the Hogan case did not justify Tarleton's, 'hostility', and, 'false aspersions' ${ }^{165}$ After all, Hogan had consistently broken the law and tricked Tarleton into questioning the, 'steadfast impartiality,' of the SPCA's work. Hogan was typical of those owners who saw their horses, 'simply as beasts of burden, or articles of merchandise,' and believed that they had, 'a right,' to treat horses as they liked. ${ }^{166}$ Despite opposition and misrepresentation, the SPCA did its work with 'discrimination, judgment and forbearance'. But the society's morale was dented by the difficulties of finding enough legal evidence to support their, 'moral evidence,' of cruelty. ${ }^{167}$ Cases of brutal flogging, kicking and mouth wrenching were especially difficult because Duggan was defeated by the, 'technicality of evidence,' and failed to secure, 'the rights of justice'. It was especially difficult to punish the owners as well as the drivers of horses. Tarleton demanded proof in criminal cases that the owner knew that his horse was in an unfit condition to be worked and that evidence was

$161 \mathrm{M}, 15$ September 1880 , p. 3.

162 M, 29 March 1879, p. 2.

163 M, 24 February 1882, p. 2, 6 March 1882, p. 2.

164 M, 25 March 1882, p. 3, letter by James Macfarlane.

165 M, 28 February 1882, p. 2, 27 March 1882, p. 2.

166 M, 14 November 1882, p. 2.

167 Seventh Annual Report of the TSPCA (Hobart, 1885), p. 8. 
difficult to obtain. ${ }^{168}$ Typically in cruelty cases it was not always easy to determine whether suffering was, 'unreasonable or unnecessary,' and much depended on the circumstances of a particular case. ${ }^{169}$ While, 'the wretched sympathy with wrong and wrong-doers,' continued, 'to disfigure our Tasmanian people', Gellibrand felt that they faced, 'an uphill effort,' to win their, 'virtuous struggle,' and represent, 'Great England's humanity'. ${ }^{17}$

After Tarleton retired to official acclaim in 1894, his successor as Police Magistrate Bernard Shaw continued his policy. ${ }^{171}$ Shaw exercised his power feebly and his, 'sympathy actively works for the offenders', Gellibrand alleged. ${ }^{172}$ Statistics supported her case. In 1895-96 the average penalty imposed in Hobart was $6 \mathrm{~s} 1 / 2 \mathrm{~d}$, whereas in Victoria it was $£ 2$ and in Otago $£ 26 \mathrm{~d}^{173}$ In 1899 one anonymous member of the TSPCA thought that such a, "very influential body of people,' put up with an inadequate law for too long and lacked, 'that burning zeal for better legislation,' that was badly needed to redress current wrongs. ${ }^{174}$ The revival of the SPCA's public activity in 1904 was accompanied by more vigorous legislation.

Animal cruelty legislation had been strengthened in Britain and other Australian jurisdictions by the early twentieth century and Tasmania lagged behind. ${ }^{175}$ In October 1904 member of Parliament for Cumberland, lawyer and farmer John Dennistoun Wood, arguing that every animal was, 'susceptible of enduring great pain', consulted the TSPCA before introducing a new Bill based on Queensland legislation. It extended the law's protection from domestic animals to any animal or bird, whether free or in confinement. ${ }^{176}$ Wood's amendment drew on English law to empower justices to impose imprisonment of one month instead of a fine for a range of offences including, 'overworking,' and, 'causing unnecessary suffering'. Another amendment 'authorised the destruction of any animal so diseased or injured that its existence would be a cause of misery to it' ${ }^{177}$

168 M, 1 April 1891, p. 2.

169 P. Sankoff, 'The Welfare Paradigm: Making the World a Better Place for Animals?' in Animal Law in Australasia, (eds) P. Sankoff and S. White (Leichhardt, 2009), pp.14, 20.

170 M, 1 December 1892, p. 3, letter by M.S. Gellibrand.

171 M, 22 September 1894, supplement, p. 1, 29 September 1894, p. 3, letter by 'Humanitas'.

172 M, 12 January 1897, p. 4, letter by M.S. Gellibrand.

173 M, 27 November 1896, p. 3, letter by M.S. Gellibrand.

174 M, 22 July 1899, p. 3, letter by 'Facts'.

175 Jamieson, pp. 23-28.

176 M, 1 October 1904, p. 6.

177 M, 17 October 1904, p. 7. 
The new Act did not greatly change the society's focus, but did help with prosecutions for overloading and over-driving of horses. ${ }^{178}$ After Bernard Shaw's retirement in March 1904, the new Police Magistrate for Hobart W.O. Wise, interpreting the law more sympathetically, showed a greater willingness to impose, 'deterrent fines,' for, 'wilful or thoughtless,' cruelty to animals. ${ }^{179}$ The clearest example occurred in February 1905 when Thomas Johnson, alias George Birchall, felled his horse with a stone, kept hitting its head and left it lying in a drain until the next day before killing the animal and removing it on the order of the Sandfly Road Trust. ${ }^{180}$ Wise called this, 'the grossest case of cruelty that had ever come before the court'. As Johnson had not paid two previous fines for other offences, Wise sentenced him to one month's imprisonment, but would have made it three months if he had the power given by English legislation. This was the first imprisonment for cruelty and much to the society's satisfaction Wise continued to impose severer sentences than his predecessors. ${ }^{181}$ Cases prosecuted by the society were still sometimes dismissed mainly because perjury was a common practice, witnesses were reluctant to attend court and, 'uncertainty,' remained over the definition of overdriving, overloading and starving. ${ }^{182}$ These difficulties and the gradual transition from the horse to the motor car resulted in a drop in the number of prosecutions: between July 1904 and 1913 the annual average was 19.1. ${ }^{183}$

From 1904 until it suspended activities with the onset of war in 1914 the society continued its work of inspection and prosecution where cautions were disregarded. ${ }^{184}$ But active members remained in short supply (membership was a low 137 in 1913) and much of the burden fell on Inspector Large and the new secretary, former educationalist Miss Fanny Garrett, who made animal protection work, 'the main object of her life,' until her death in $1926 .{ }^{185}$ Garrett was more circumspect than Gellibrand and the society generally remained moderate in outlook, avoiding, 'the realm of public spectacle'. ${ }^{186}$ The work of the TSPCA was

178 Minutes of TSPCA, 3 February 1905, NS 647/1/1, TAHO. Native fauna and birds were regarded as outside the purview of the society.

179 M, 27 August 1904, p. 7.

180 M, 15 February 1905, pp. 4, 6.

181 Minutes of the TSPCA, 23 June 1905, NS 647/1/1, TAHO; Tasmanian Nerws, 16 November 1905, p. 2.

182 M, 14 March 1906, p. 5.

183 These figures are compiled from statistics given in annual reports.

184 M, 18 June 1919, p. 8.

185 M, 27 March 1908, p. 2, letter by H.T. Gould; Thirty-Second Annual Report of the TSPCA (Hobart, 1910), p. 7; Thirty-Sixth Annual Report of the TSPCA (Hobart, 1914), pp. 16-18. 186 Kean, p. 145. 
complemented by the formation of new bodies focusing on the welfare of native animals and birds such as the Field Naturalists' Club, the Gould League of Bird Lovers and the Anti-Plumage League. ${ }^{187}$

After nearly thirty years of operations, the society came to realise that laws 'will not make men and women humane, any more than it will make them moral'. ${ }^{188}$ As the Mercury put it, dependence on, 'prohibitory legislation and the power of punishment,' would not result in, 'radical improvement,' in, 'the habit of mind,' that perpetrated, 'barbarous conduct'. The society thus renewed its efforts to form Bands of Mercy, mostly dormant since 1890. In 1907 parents and teachers were urged to inculcate in children, 'the duty of being kind and considerate to all dumb creatures', especially domestic animals. ${ }^{189}$ By 1909 eighteen Bands of Mercy had been formed. ${ }^{190}$ Many of the essays written by children for the prizes offered by the society showed, 'great love for animals, close observation, and great kindliness of heart'. ${ }^{191}$ Another educational initiative was the society's appeal to the clergy to preach on, 'Man's Duty to Animals,' as was done regularly in England. ${ }^{192}$ Animal Sunday sermons were first given on 12 July 1908 and became an annual event in some churches, but reached only small numbers of people.

\section{Conclusion}

In 1914 the TSPCA annual report wrote that the RSPCA had grown from, 'a tiny band of despised and almost penniless enthusiasts to a powerful Society,' that had, "influenced and raised the tone of public morals, and spread its teaching into all parts of the civilised world'. ${ }^{193}$ The TSPCA had overcome similar opposition, inadequate funding and the added difficulty of changing behaviour in the capital city of an ex-penal colony. It discharged its duty to protect animals by adhering to the, 'aims and ideals,' of, 'our Parent Society,' and by being inspired by its successes.

By May 1912 the TSPCA had noted significant changes, helped greatly by its enforcement of the law and educational initiatives. It found evidence of, 'greater sensitiveness of public conscience and opinion, with acceptance of the rights of

187 Thirty-Fourth Annual Report of the TSPCA (Hobart, 1912), p. 11.

188 M, 15 March 1906, p. 4.

189 M, 13 July 1907, p. 7.

190 M, 17 March 1909, p. 6.

191 Thirty-Fourth Annual Report of the TSPCA (Hobart, 1912), p. 13.

192 Minutes of the TSPCA, 13 July 1908, NS 647/1/1, TAHO; M, 17 March 1909, p. 6.

193 Thirty-Sixth Annual Report of the TSPCA (Hobart, 1914), p. 11. 
animals, and of man's duty towards them'. ${ }^{194}$ In Hobart, 'cases of neglect and abuse,' were immediately, 'noted and disapproved'. Drivers of horses, 'readily invited and acted on advice for sick animals,' and accepted offers of literature on the subject. Hobart had certainly not been purged of cruelty to animals, but we should not underestimate what had been achieved. The civilizing mission of the TSPCA had helped to change long entrenched practices, took great efforts to ensure that the law was of more than symbolic protection to animals, and contributed to the, 'uplifting and ennobling,' of city life. ${ }^{195}$ But after the war attitudes to animals changed and cases of cruelty became more common, requiring renewed efforts on the part of the TSPCA to awaken Hobartians to their responsibilities to animals. ${ }^{196}$

194 M, 24 May 1912, p. 6.

195 Thirty-Sixth Annual Report of the TSPCA (Hobart, 1914), p. 11.

196 M, 17 June 1921, p. 6, letter by 'Pip', 28 May 1923, p. 6. 